\title{
Ernst Plischke as Teacher: Wellington (Auckland) Vienna
}

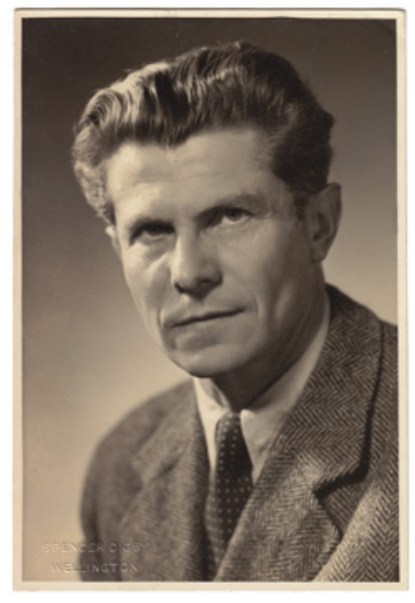

Fig. 1 Ernst A. Plischke, 1947. [Photograph by Spencer Digby, Wellington]
From early on in his career, Austrian-born architect Ernst Plischke (1903-1992) wished not only to be a practising architect but also to be able to pass on his knowledge as a professor. As an émigré in Wellington in the 1940s, he was able to give small series of lectures, sometimes in private circles, at other times in collaboration with the Architectural Centre. In 1947, he applied for a position of Chair of Design at Auckland University College. Although interviewed, the University preferred Charles Light, a Beaux-Arts trained, English candidate with considerable teaching experience. Instead of teaching at university, Plischke began his successful career as an independent architect (in partnership with Cedric Firth).

Sixteen years later, in 1963, Plischke left New Zealand to return to Vienna. While giving up his practice in Wellington, he was finally able to teach architectural design. For 10 years until 1973, Plischke taught his Master class at the Academy of Fine Arts. The teaching aspect of his career has not previously been researched extensively. In his autobiography of 1989, Plischke shows a few projects from this time, while Sarnitz and Ottilinger in their 2003 catalogue of Plischke's complete works only touch this subject ever so lightly. The most thorough documentation of his teaching stems from a 1976 publication of student designs, while the best documentation of the long-term results of his teaching is the collection of essays by his former students and assistants (also 2003) in which fourteen contributions are devoted to Plischke as teacher.

Some of his former students have formed the Plischke Society to keep the memory of their teacher alive. This alone indicates that Plischke had given more than just ordinary teaching. Plischke is well known as a staunch supporter of modernist architecture-indeed, of a light, elegant modernism. Did he teach what he practised? Drawing from literature and personal conversations, as well as archival material, this article aims to show that while Plischke was strict in expecting architectural modernism of a high quality from his students, more important to him may have been to teach his students a moral compass, to develop an underlying noble mind that would support their architectural endeavours. 


\section{A Modernist Architect with a Strong Sense of Aesthetics}

Plischke and his Jewish wife Anna came to New Zealand in 1939 as refugees from the Nazis in Austria. From early on in his career, Plischke had developed a reputation as a modernist architect, and as such he was an exception in Austria. One of his best pieces of architecture is his Employment Centre in Vienna's suburb of Liesing (1930-31). This building was soon published internationally, for example by Alberto Sartoris in Gli elementi dell'architettura funzionale of 1935; but although the book title indicates functionalism, Plischke's architecture was driven by a strong underlying aesthetic sense, combined with his understanding of site, programme, and construction.

Having studied under prominent architects such as Oskar Strnad, Josef Frank, and Peter Behrens, all of whom were members of the Austrian Werkbund, Plischke graduated from the Academy of Fine Arts in 1926. Before emigrating to New Zealand, he was able to call a handful of houses, the double unit at the Werkbund settlement in Vienna, three employment centres, and a good 20 interior designs his realised achievements (Orosz 2003). ${ }^{1}$ At the age of 33, he had won the Großer Staatspreis - the Great State Prize, a prize newly introduced by government.

Thus, when Plischke arrived in New Zealand in 1939, he had already made a name for himself.

\section{Educational Engagement in Wellington}

Early in his career, still in Vienna, Plischke developed the wish to teach architecture, to become a professor one day. In Vienna, the circumstances did not allow this to happen. In Wellington, while working in the Department of Housing Construction, he took up the opportunity with delight to realise his dream to participate in architectural education-even if this was on a modest level.

As early as 1941, he was invited by the Wellington Architectural Students' Club to deliver a lecture. Plischke reports to his life-long friend and confidante, the renowned potter Lucie Rie (1902-1995):

The club of the students of architecture invited me to give a lecture on modern architecture. I spent plenty of time to prepare this lecture and enjoyed these preparations immensely. Then the material became too much for one evening, so we had to have a second one. We had a projector which enabled me to show them plenty of my foto-cuttings; if you remember them. After the first lecture for the second evening there came also our chief architect with his wife, the assistant architect and also private architects who had heard about it. We had lots of fun out of this evening and especially for the youngsters it was absolutely new and exciting (Plischke 1941). ${ }^{2}$

Thus, with some right, Plischke may have felt that he was able to attract an interested audience when speaking publicly about architecture. A little later, he was asked to deliver lectures at the History Department of Victoria University of Wellington, both in 1943 and in 1945. Plischke writes to Rie:

I already have another and quite pleasant private job. I have been asked to have a serie[s] of lecture[s] at the university out here. I may pick any theme I like and they want to have it in the way of kunsthistorisches Seminar with 
discussions and so on. I hope that I will like it very much (Plischke 1943, April 19).

The "kunsthistorisches Seminar" was like a university seminar in art history, indeed on the topic of the Fine Arts. The seminar finished by the end of September. In a further letter, Plischke adds: "There were ten of [the lectures], one every week, perhaps the greatest fun I had since I am here, very exciting but also very strenuous" (Plischke 1943, September 30). In his application to Auckland University College in 1947, Plischke would list about 30 lectures he had presented overall (see further down).

At the same time, Plischke was able to lay down a few of his theoretical positions in two publications. Asked to write a design guide for returning servicemen, About Houses was published in 1943 by Government. This was extended into a veritable book which discussed good modern design on three scales-the interior, the house itself, and the urban environment. Design and Living, published in 1947, allowed Plischke to contribute to the design education of the general public.

His engagement in educational activities in Wellington extended into the early years of the Architectural Centre. The Centre was created at a meeting on July 23, 1946. Plischke was present, amongst architects such as Graham Dawson, Gordon Wilson, Helmut Einhorn, and Fritz Farrar, the two latter also being émigrés, and a group of students. Plischke became part of the executive committee (Salinger 1996: 69-78). He also participated in the publication of the Centre's journal, the Design Review, both with articles on his own work and, for a period, as member of the editorial board. As we have seen, Plischke had already delivered lectures to the Wellington Architectural Students' Club five years before the Architectural Centre was founded.

Because the only architecture school in the country was in Auckland, a strong driver for the Architectural Centre was to assist "students with their study in the form of an atelier"; thus with support from the Housing Division and Town Planning Office of the Ministry of Works, "in 1947 the Centre ran its first course in architecture" (Salinger 1996: 74). Plischke was invited to take part in the 194849 summer school studio session, which was held in August 1948. This was the starting point for the design and building of a contemporary prototype house, which became known as the Demonstration House (Gatley 1996: 89-95; Gatley \& Walker 2014: 35-39). In this, Plischke was joined by his former superior, Gordon Wilson-"an interesting pairing", as Julia Gatley and Paul Walker observe, "given their much-hyped personality clash" (2014: 36). All of these moments show Plischke's wide engagement with architectural education of students as well as of the general public.

After leaving the Department in late 1947, a new phase in Plischke's life began when he officially went into partnership with Cedric Firth. The two young architects had met in 1939 in the Department of Housing Construction and began to cooperate soon thereafter, ${ }^{3}$ while officially setting up their joint office as Plishke $\&$ Firth in early 1948. In Firth, Plischke found an equally committed supporter of modernist architecture. Firth had trained as a builder and studied at Auckland University College before travelling to Europe in 1931 and 1932 (Bowron 2000). 


\section{Application at Auckland University College}

In December 1946, Auckland University College advertised for a Chair of Design in the School of Architecture (AUC 1947: 378-78a). Student numbers in the School had continuously increased from 66 in 1943, to 210 in 1946, and would continue to grow. Considering this increase, another two positions were advertised in 1946, that of a lecturer in construction and a permanent librarian (Gatley 2017: $42,44)$. Also in 1946, several students had formed the Architectural Group, writing in their constitution that they would work on a development towards "1) group practice ... on a co-operative basis" and " 2 ) ... to achieve an organization of planners and builders similar to the Deut[s]che Wer[k]bund, and including the ideas of the Modern Architectural Research Group [MARS, London] and the Association of Building Technicians in England" (Architectural Group 1946, in Gatley 2010: 20). Here was a call, made by young students, for modernist architecture in New Zealand. This would manifest itself a few years later in the Group Construction Company houses, designed and built by the Group in Auckland.

Ernst Plischke was made aware of this opening by friends, suggesting he apply. He writes to Rie:

Since my last letter we had again a bit of excitement, but not too bad. Five months ago a new chair for design was created at the architectural school of Auckland University. It was advertised all over the empire. It is the only architectural school in New-Zealand. Some friends thought that I should apply and that I even might have a chance (Plischke 1947, June 14).

It was a new position, needed because of the increased student numbers, to be filled by someone who would work closely with the Dean, Cyril Knight-on whom Cedric Firth commented in a letter to Plischke: "Good Prof. Knight, may his bones rest in hell if not in worse" (Firth 1948). Knight, an Australian who had studied in England, Paris, and the United States, had been Professor and Dean at Auckland University College since 1925. He had set up the Bachelor of Architecture, which started in $1926 .{ }^{4}$ Both his education and teaching had been strongly focused on Beaux-Arts methods and practices. Firth elaborates upon his criticism, made in the context of a visit he paid to architects at Harvard and MIT. On this occasion, he met with Professor William Wurster and Walter Gropius, calling the latter "an old and disillusioned man". He also says, however, that Wurster's and Gropius' work at these schools "makes the School at Auckland look quite foolish, and quite incredible” (Firth 1948).

Plischke put together his résumé and sent it off to Auckland-and to London, where the jury was assembling. Professor Lionel Budden of the University of Liverpool had been chosen as chair of the committee in England. Apart from Budden, this consisted of four officials, representing the Royal Institute of British Architects Board of Architectural Education, the Architectural Association School of Architecture, the Universities' Bureau, ${ }^{5}$ and the University of New Zealand. ${ }^{6}$ In a 2010 paper, Christine McCarthy has attempted to clarify the decision-making process for what might have become Plischke's professorship in Auckland (McCarthy 2010: 258-64). She discusses the composition of the appointment committee in detail, in order to determine a possible bias of the committee towards the Beaux-Arts or modernism. While this seems to be difficult to establish in retrospect, she concludes that Budden himself, although "a clear adherent to the Beaux Arts", was sufficiently liberal and modern to steer 
the University of Liverpool towards the teaching of modernism (McCarthy 2010: 260-61). Budden compiled a shortlist of six of the 12 applicants for interview. These were the candidates: Ashworth, Breakwell, Bulmer, Harvey, Light, and Wood. "Professor Budden indicated that in his opinion Mr. Plischke would have been included in this list had he been available in England" (AUC 1947: 380). Plischke was considered to be a suitable candidate but could not be interviewed together with the other six shortlisted applicants. Thus he was in the strange situation to remain outside the main application process although he was present in the country where the position was to be filled. The interviews in London were conducted on April 21, 1947. The committee unanimously agreed on Charles Light as their preferred candidate, with Harry I. Ashworth as the runner-up. However, the committee saw itself "unable to recommend the appointment of any of the other candidates which it interviewed" (AUC 1947: 381).

A month later, Ernst Plischke was interviewed in Auckland. He had been given relatively short notice, receiving the telegram on May 20, six days before the interview (Registrar, 1947). He travelled to Auckland via plane. The AUC Council Minutes of May 26 state that "Mr. E. A. Plischke was interviewed by Council" and recommend that the chair be offered to Charles Light while asking the Senate "to approve of the following four applicants: H. I. Ashworth, R. H. Bulmer, A. C. Light and E. A. Plischke" (listed in alphabetical order and thus not giving away any hierarchy of the list) (AUC 1947: 350). In the letter to Rie from June 1947, Plischke summarises:

A few days ago I got a cable to come to Auckland for an interview of the council. The chairman and part of the council was for me but the other professor who is Dean of the faculty was dead against me. He wanted of course an Englishman, with the routine experience of teaching, and [who] would be a mediocre architect and be no competition for him. So the final toss-up was between the Englishman and myself. Now his appointment has been announced in the newspaper (Plischke 1947, June 14).

The "other professor who is Dean of the faculty" and who was "dead against" Plischke, was Professor Knight. With the assumption that "the Englishman" Light would be no competition for Knight, Plischke indirectly says that he would foresee a competitive situation between himself and Knight because of his own strong architectural convictions that would not (easily) be reconcilable with those of Knight.

Returning to Wellington, Plischke muses over the event in a diary entry of the interview day. In view of the unfortunate circumstance that no official records of the interview have survived, ${ }^{7}$ his recollection is the closest we will get to know about the conversation that took place:

Whatever I said, Knight would have found it unsuitable or insufficient; either too aggressive or not forceful enough. Teaching experience as precondition. I have no English education. They asked many questions that were already answered in the application ... Apart from Knight no one asked a question. It is just as well that the antagonism with Knight became visible now and not too late. Had I talked as I wished, there would have immediately been a row with Prof [Knight]. Should I have presented a prepared lecture? ... Creative force of NZ youth. If I had ever enquired if the RIBA recognises our degree. Prof. Knight did not query my qualification but that it is not a 
British training. What ever I could have said in my favour was an attack on Knight ... I would endeavour to link my teaching - the work of the students-as closely as possible to the practice background and conditions of practice and every day life (Plischke 1947, May 26). ${ }^{8}$

Plischke seems to have seen correctly that his lack of teaching experience presented a difficulty. Although the advertisement, while specifically asking for "qualifications and experience in Architectural Design", did not require a mention of teaching experience (AUC 1947: 378), in his application he had named all the lectures he had presented so far:

A series of ten lectures on Fine Arts ... in the History Department, Victoria University College, Wellington, in 1943 ...

A series of ten lectures at Victoria University College on the design of modern houses as an adult education course in 1945.

Several lectures for the Army Education Service ...

A lecture to a Conference of the New Zealand librarians in Auckland on Community Centres.

Lectures on design and criticism of esquisses for the Wellington Architectural Students' Club.

Three lectures on problems of modern design to the Architectural Centre Summer School of Design, Wellington. (Plischke 1947, February 3: 3)

About 30 lectures are surely more than nothing, but this enumeration certainly does not compare favourably with the comprehensive teaching and administrative experience of some of his competitors. Plischke also saw clearly that his lack of an English background made it more difficult for him to be successful. Whether his perceived discord with Professor Knight would have been as strong in reality as it was in his imagination cannot be answered. And given his difficulties with other strong minds-such as Clemens Holzmeister in Austria or Gordon Wilson in Wellington-it might very well have.

Julia Gatley reiterates McCarthy's findings, stating that "Plischke [who] was a respected architect, was never a strong contender for the position because the College sought a person with both practice and academic experience, and Plischke had comparatively little of the latter" (Gatley 2017: 44-45). While the job description stated the "right to private practice" (unless it interfered with the duties at the College) and required a statement about the candidate's experience in architectural design, the advertisement was surprisingly mute on both the expected teaching experience and practice experience (AUC 1947: 378); in this, the ad was perhaps imprecise. And the surprise is that Charles Light who was appointed as Professor, as per the short CV in the Council Minutes, did not have any practice experience at all. He had indeed won important design prizes-but there is no mention of running an architectural practice or having been employed in one (AUC 1947: 374).

Plischke thought that in the end it came down to a decision between Charles Light and himself, and until the end of his life this is how he saw the event. ${ }^{9}$ This possibility cannot be ruled out entirely for two reasons: the committee in England saw itself "unable to recommend the appointment of any of the other candidates 
which it interviewed", and the fact that Plischke was able to refer to the shortlist of two can only mean that members of the Council at his interview must have indicated as much. So perhaps "the final toss-up" was indeed between Light and himself, even if McCarthy claims that this was not the case (2010: 262). First, she notes that "the short-listing privileged experience and post-graduate qualification over practice, and experience over youth" (2010: 261). With this in mind, she re-formulates her question to ask whether or not another one of the British candidates should have been offered the position. This was William Walter Wood, a practising modernist architect with teaching experience who already had been Head of School at three polytechnic schools (2010: 261). McCarthy concludes that on strength of the material available, William Wood would have been at least a strong contender for the job, if not better suited than Light. But he was not chosen-and so this hypothetical scenario is perhaps unrewarding.

However, McCarthy importantly points out it appears that the English "committee's bias was against a professor conducting practice" (2010: 262). Indeed, the report by the Universities' Bureau clearly argued against this possibility by stating William Wood was "a very ambitious man, but the Committee considered that he was likely to be more interested in the building up of a large private practice than in the development of a University School" (AUC 2010: 381). Plischke might easily have received the same comment had he been present at the interviews in England: his thought after the interview that "I would endeavour to link my teaching-the work of the students-as closely as possible to the practice background and conditions of practice and every day life" makes his position on the relationship between teaching and practice very clear. And it is a useful, modern position that would resonate in any similar application today. In a letter of June 1, 1947, to his family back in Vienna, Plischke goes into more detail, and his thoughts regarding teaching and practice seem relevant here:

Last night then was the meeting of the University Council and I [was] presented and interviewed. Of all the applicants only one architect in England and myself are left on the shortlist. Very honouring, isn't it? The President of the Senate absolutely wants me. The Dean (of the Architecture Faculty) wants the Englishman. Here, a teaching architect has not been allowed to practice until now. This is different for this new position, since one begins to accept that practice is important also for teachers. But it is an innovation. As of yet, an applicant for a teaching position only had to demonstrate teaching practice at other schools ... The Senate is divided and I think that the Englishman will get the position. When I realised this during the interview where the Dean was present, I got very depressed and disappointed (Plischke 1947, June 1). ${ }^{10}$

So what emerges from a renewed study of the application process, with new material by Plischke at hand, is that the committee-and thus, one has to conclude, Auckland University College-was not sufficiently interested in a Professor of Design who would continue to maintain a design practice. Charles Light was their preferred candidate because of his uninterrupted academic experience and because he did not "threaten" to practise. As McCarthy has shown, his inclination towards the Beaux-Arts might have helped.

Perhaps Plischke's last sentence in his reflections on the train back to Wellington can open a discussion: in the Universities' Bureau report on the applicants, Light 
was recommended for being "the only one of the candidates who appeared to have a clear conception of how to teach the theory of design" (AUC 1947: 380). It would be interesting to compare Plischke's ability to formulate his own theory of design: How would the committee have judged him? Plischke had continuously developed his own theoretical stance on architecture and design since the early 1920s and had advanced far beyond what he was able to lay down in Design and Livingwhich had been published almost at the same time as the interview in Auckland was conducted. ${ }^{11}$ Would he have been able to convince the jury in London?

It seems important here that Plischke, who in his own personal reflections often maintained the need for an Innerlichkeit, perhaps to be translated as inwardness that reflects one's fundamental stance towards life as a whole, in these notes referred to the "conditions of practice and everyday life": he had become well versed in the conditions of the making of architecture in New Zealand and understood what the students would benefit from. Plischke had both an interest and an ability to put himself in the students' shoes.

But perhaps that was only one aspect of the story. In 1947, resentments against Germans (or, as in this case, German-speaking people) were still running high (Beaglehole 1988). In a twist of irony, Plischke's disadvantage was not only to be of the German language but through being a migrant in the colony he had become somehow a local. He was the only applicant who lived in New Zealand. Seen from today's perspective, the intimate local knowledge (own practice, planning for Government both in housing and in town layouts and community centres) should have given him a solid advantage over any other non-local applicant.

This question of teaching experience remains, and is to be re-considered in the light of his appointment in Vienna: at the Academy in Vienna, teaching experience was not even considered. What counted was that candidates were prolific practising architects.

\section{Appointment at the Academy in Vienna}

In January 1960, while still in practice with Firth in Wellington, Plischke received a letter from architect Roland Rainer, who at the time was Rector of the Academy of Fine Arts in Vienna. Rainer enquired if Plischke was willing to return to Vienna to become full Professor at the Academy (Rainer 1960). To add to the surprise, this meant that Plischke would take over Clemens Holzmeister's professorial chair. Holzmeister (1886-1983) was a successful and politically active conservative modern architect who had emigrated to Turkey in 1938 and returned to Austria in 1954. He had been Plischke's nemesis in the years before the war. Or so at least Plischke felt. He saw Holzmeister as being directly behind his difficulties in obtaining any commissions after 1933 and believed Holzmeister had been against him winning the Great State Prize in 1935 (Plischke 1989: 181, 199). With his first assumption, Plischke may have been right, but in the second case, he erred: as part of the jury, Holzmeister had suggested that Plischke should win this prize, giving consideration to the many difficulties he encountered as a young architect in 1930s Austria (Posch 2010: 254).

Plischke answered Rainer with ambivalence: in his letter of January 18, he speaks about their "lovely house and beautiful big garden" and about a hesitation to "deal with the question what a new uprooting and a back-transplantation would 
implicate"; first of all he wished to discuss technical details with Rainer (Plischke 1960). ${ }^{12}$ But in the ensuing correspondence between the two architects, Plischke did show himself prepared to leave New Zealand in principle. His wife Anna agreed more reluctantly since it meant a lot to her to be close to her adult sons (Henry Lang living in Wellington and Franz Lang living in Sydney, both with their families). Still, in the following three years, Plischke went through various phases of ambivalence and agony: this is how long the decision-making process in Vienna took. Again and again, he did not know whether they would finally leave for Austria or not. For example, on May 20, 1960, he writes to his friend Rie, expressing his unease:

We live and work as usual, but in reality everything is totally unsettled with us. One day we think we are leaving N.Z. for good-sell our house and the garden where we have taken roots during those 20 years and go back where we left then. Another day we kind of hope that we stay here. No, Lucie-I have no illusions; I am very aware of the mental climate of Vienna from our last visit (Plischke 1960).

With this last comment, Plischke refers to his first visit back to Vienna in 1953, to celebrate his 50th birthday. He had not seen his family since their emigration in 1939. However, in Vienna he experienced an overwhelming disgust at the continued presence of "Nazis" - those who had either been in power during the Third Reich or been opportunist followers. A return to Austria was, if not impossible, at least loaded with mixed feelings. However, Plischke's attitude changed, and he did hope to be appointed in Vienna, while remaining very sceptical that it might not happen. In this letter, he continues:

Anyhow I think the whole lot of trouble is again a waste of time-there is no real likelihood that they will take me. In their coalition proporz [proportional representation] system $50 \%$ is red and $50 \%$ black-Rainer is the red half and Holzmeister and his chair is the black one. I have never been or will be a Clerikaler [cleric] in my life. And that is what finally counts with the people who make the decision (Plischke 1960).

This is a reference to the political system of post-war Austria which, in some ways, has been continued until this very day, with half of posts and jobs being given to social democrats and the other half to members or allies of the conservative party (Berger 2007: 278-81).

Implicitly, Plischke also refers to a letter by Holzmeister of a few weeks earlier (April 1960) in which Holzmeister speaks of his Chair and that the Institute for Sacral Art was attached to it. Because he wanted this tradition to be continued, he was keen to know whether Plischke had built any churches (Holzmeister 1960). The leading nature of this question annoyed Plischke and, in his eyes, demonstrated the politicisation of this case (A. Plischke n.d.). In his scepticism, Plischke was right in principle, however, in this case his worries were unnecessary: Rainer had prepared the ground for Plischke long before 1960; at least that is what appears to be the case when we closely follow the faculty meetings at the Academy.

Roland Rainer (1910-2004), seven years younger than Plischke and a prolific modernist architect, had brought Plischke up for discussion in these meetings as early as 1957, repeating his mention of Plischke's name several times up and until 1960. Thus, it seems that Rainer was eager to make his colleagues aware 
of Plischke and his achievements-perhaps to prepare them for a favourable decision at a later date. And if this was his tactic, it was fully successful. In the meeting on June 24, 1960, Rector Professor Christian Martin informed his colleagues that:

Professors Dr Rainer and Dr Holzmeister have asked to set the replacement of the chair of the Master School, Prof Dr Holzmeister, on the agenda.

Simultaneously, those above-named professors have named following architects for a list of three candidates, to be suggested to the Federal Ministry of Education:

Ernst Plischke, born 26 June 1903, in Austria, currently in New Zealand;

Arne Jacobsen, born 1902 in Copenhagen, Denmark;

Heikke Siren [sic], born 1918 in Helsinki, Finland. (Academy of Fine Arts Vienna 1960)

Martin concludes by saying: "Prof Dr Rainer emphasized that the above named were outstanding and world-renowned architects. This dignifying appointment alone would cause a sensation in architectural circles internationally and bring honour to the Academy" (Academy of Fine Arts Vienna 1960). This was indeed something of a coup since by naming the world-famous Arne Jacobsen, Plischke's own standing was automatically strengthened. Was it Rainer's calculation that Jacobsen would not accept the offer anyway? This is not to say that Plischke would not have had an impeccable reputation in his own right. But being compared to an internationally renowned architect like Jacobsen would have helped Plischke's position. Jacobsen indeed declined the offer. In the end, the list was changed to Plischke, German architect Egon Eiermann, and Heikki Sirén. In the decisive meeting of May 1962, the group of professors at the Academy agreed to Rainer's suggestion and recommended Plischke as their first choice (Academy of Fine Arts Vienna 1962). It was not until March 1963 that the council of ministers accepted Plischke's appointment.

\section{How Much does Teaching Experience Matter?}

Does it matter if a candidate for Professor of Architectural Design-whatever the actual job title-has considerable teaching experience when appointed? It seems that the German and Austrian system differs fundamentally from the system employed in Britain and New Zealand in this regard. Without going into depth about cultural differences in educational systems-here Anglo-Saxon, there continental-one can observe a different attitude with regard to the way in which practice experience in architecture is acknowledged.

For the Austrian professors at the Academy of Fine Arts in Vienna, there was no question whether Plischke (or any other of their suggested candidates) had teaching experience or not. What mattered was that the new Chair would have the design experience and international standing that would allow him to attract and educate keen students. The selection process of the new professor was also different from the British procedure: in Vienna the members of the faculty made suggestions as to whom they would like to appoint as a new Chair-that is, as their new colleague. This is, of course, fundamentally different from applying for a job opening. In New Zealand in 1947, things were very different. 
There is the question whether a design professor should be a career academic or a practitioner who teaches students, while keeping his practice. It appears that in the Auckland process the committee preferred Light over the other candidates not only because of his ability to teach and administer but also because he presented no "threat" of suddenly wishing to practise. They said:

... and though he has a good deal of practical architectural experience the Committee has no doubt that his chief interest lies in teaching and it does not consider him likely to wish to develop a private practice to the detriment of his teaching duties (AUC 1947: 380).

While from the committee's point of view this judgment makes perfect sense, it means that such a system sees no merit in the knowledge transfer that happens between teaching and practice. The German/Austrian system which is based on such transfer is not without conflicts for exactly the reasons that the committee had outlined in the case of Light and Wood: often, design professors find it hard to combine their teaching with a successful running of their practice. Since it is their practice experience that helped them obtain the position in the first place, it is often seen as desirable by the university that the professor in question keeps up his practice, with all the ensuing time and workload conflicts. The author of these lines has seen many cases in which this works well and an equal number of professors for whom it became necessary to decide for the one or the other.

Would Plischke have made a good professor in the sense of what Auckland University expected? Perhaps not. As mentioned, he recorded in a note to self: "I would endeavour to link my teaching-the work of the students-as closely as possible to the practice background and conditions of practice and every day life" (Plischke 1947, May 26). Here, Plischke stresses the point of practice-and probably did so in the interview. He had no wish to give up practicing at all. In fact, he would resign from the civil service at the end of 1947 to go back into practise from January 1948 onwards - and thoroughly enjoyed this move: "Altogether I am satisfied, especially I enjoy my freedom” (Plischke 1949).

\section{The "Graph", the Essence of Plischke's Architectural Thinking}

Two years after his return to Austria, Plischke was appointed Rector of the Academy. That year, 1965, he also gave his inaugural speech at the Academy. In it, Plischke brought together his lifelong grappling with the contradictory elements of architecture in one precise but flexible definition. Not often in his career did he get the opportunity to define, to the point, his theoretical position. Here, the occasion allowed him to make a programmatic statement about his fundamental attitude towards architecture. He says:

In my view, the aim of a fully developed modern architecture needs to be the unity of a spatial concept on the one hand and a Bauplastik [a built sculpture] on the other hand. These two qualities nevertheless need to be developed from a fulfilment of the function of the building and of its structure.

The principal quality of such a fully developed architecture lies in the tension between the spatial concept and the building's function on the one side and the vision of a sculptural building and the structure on the other hand. Only this tension brings a building to life, and makes its architectonics 
noticeable. Without this tension we end up with either pure utilitarianism or with an abstract built sculpture (Plischke 1965b: 11-12). ${ }^{13}$

In this definition, which he later completed with an explanatory diagram which he called the "graph", Plischke does something very interesting: he extends the Vitruvian triad of utilitas, firmitas, venustas (utility, firmness, beauty) by splitting venustas into two aspects: the interior and the exterior beauty-space and sculpture. Through this manoeuvre, he arrives at a construct that allows him to identify the tensions between its elements: between space and function on the one hand and sculpture and tectonics on the other hand. These tensions are well-observed, and through this comparison Plischke demonstrates an understanding of an essential principle of architecture. This understanding was not only central to his own design work, he also placed it at the heart of his teaching.

\section{A Supportive but Strict Teacher}

Plischke would teach his Master class at the Academy for 10 years, from 1963 to 1973. Classes were small, with about 10 students per year. A total of 103 students graduated from Plischke's class, while another 86 studied one or more semesters in his class. These are small numbers, and they may highlight the more personal approach to teaching in this type of Master class, compared to today's year groups in New Zealand architecture schools.

In 2002, 10 of his former students formed the Ernst-A.-Plischke Society in Vienna to keep the memory of their teacher alive. To honour the centenary of Plischke's birthday in 2003, they decided to publish a book with essays on their former professor. The list of 10 grew into 25 names of contributors to the book that is now jokingly known as the "red book" (because of the colour of its cover). Not all of these had been his students, some were colleagues, friends, or his assistants at the Academy. But this fact in itself indicates that Plischke had given his students more than just ordinary teaching.

In conversations, architects Luigi Blau and Matthias Mulitzer have pointed out how much Plischke strove to assist his students. Blau, born 1945, studied in Plischke's Master class from 1966 to 1973. He says: "The positive aspect of his teaching was that he tried to encourage, to support, when a student was near and dear to him" (L. Blau, personal communication, August 30, 2016). Mulitzer, who later interviewed Plischke (1985 and 1986) as preparation for Plischke's autobiography and helped assemble the material for it, was too young to study under Plischke (he graduated from the Academy in 1986). But through his conversations with Plischke he developed an intimate understanding of the Master class and Plischke's teaching. He says, almost with the same words as Blau, that Plischke tried to support his students and to help them where he could (M. Mulitzer, personal communication, August 30, 2016). At the same time, Plischke appears to have been a strict, at times unrelenting, teacher. He gave his students a heavy design workload before they would be able to receive the Abtestur-maybe "attestation" in English. Mulitzer describes it as giving his students "hard nuts to crack". Apparently, Plischke added detail on detail drawing before he approved a design. Where there was a difference in opinions, he would argue with his students, "but", as Blau asserts, "not in a bad way, instead disputing in a good way" (L. Blau, personal communication, August 30, 2016). 


\section{Not Indoctrinating but Anachronistic?}

Architect Alessandro Alverà, who studied under Plischke from 1967 to 1971, states that it came as a big surprise to him that Plischke's students did not rail against their professor as was common at the other schools during the 1968 protest years: "I think that Plischke's lectures as well as his teaching style explain the loyalty of his students" (Alverà 2003: 98). ${ }^{14}$ This opens the question of how Plischke's teaching sat within the radical challenges and changes of those years.

Architect Dietmar Steiner remembers a case in which the given brief was a single-family house-in 1971. He found the idea of having to design a house for one family appalling and changed the brief into designing a communal house for 20 people. Plischke's reaction apparently was to ask: "So my Anna would have to stand in the kitchen with other women?" He then declared disinterest in the project (Steiner 2003: 126). Steiner was allowed to continue working on the project-but with one of his assistants, not with Plischke. Steiner consequently shows himself unimpressed with Plischke's teaching but remains with respect for what he calls a "relic from another time" (2003: 126).

This is an odd incident when compared with an observation of Janet Paul. Paul and Plischke had been friends since the 1940s when she designed the inscription for Plischke's 1942 Tasman Memorial. She remembers that Plischke had told her of his efforts to design with cultural awareness. Being tasked to design multi-units for Ōrākei in Auckland from 1939 onwards (Schnoor 2014: 805-16), Plischke apparently was well aware that they were intended for Māori of the Ngāti Whātua iwi (tribe), the original residents of Ōrākei:

In private conversation, Plischke later related how, since these houses were to be lived in by Maori families, he had tried to find out the future residents' specific preferences: these were for communal kitchens where all meals were prepared and eaten, as well as for the well-used deep verandas such as were commonly found in Maori meeting houses. In his initial design, Plischke had altered the small separate spaces of the kitchen, the tiny dining area, and the sitting room of the typical state house to make instead one large kitchen/living room, which opened on to a sheltered sun terrace. The sketch went up through the Housing Department as far as a final arbiter-the Prime Minister, Peter Fraser-who then rejected it on the grounds that "our Maoris deserve the same housing as is made for Pakeha New Zealanders” (Paul 1998: 193).

When he had shown so much progressive sensibility in the 1940s, how come a student's idea to design a communal kitchen in 1971 Vienna angered him?

Steiner also compares Plischke and Grete Schütte-Lihotzky, the designer of the Frankfurt kitchen of 1926. He shows himself surprised how little interest both of them showed in political and societal challenges of their time. "They followed an inner position and searched to justify it morally and politically. In that, however, they neglected much that actually developed in politics and society of these times" (Steiner 2003: 128). ${ }^{15}$ It is fair to say that Plischke, despite his closeness to the big events of the twentieth century, indeed remained surprisingly apolitical. Party politics were not his means of engaging with society. However, in his 
designs of both social housing and community centres he remained driven by a fundamentally philosophical stance towards life.

Steiner's view of a politically and socially disinterested teacher is countered by Martin Spühler's observations. Spühler, one of Plischke's many Swiss students, who graduated from the Master class in 1967, claims that Plischke's teaching allowed great freedom and was in no way indoctrinating. In trying to answer the question of why Plischke was of such sustained importance to him as a teacher, he refers to the congruence of the person Plischke and his work (Spühler 2003: 130). ${ }^{16}$ Spühler remembers Plischke's Tuesday lectures as "unsystematic but always accurately prepared", adding that the students had to assemble the whole picture from mosaic pieces. "This concept, at first sight didactically unclear in its setup, suppressed the student as consumer; it required perseverance and patience” (Spühler 2003: 131). ${ }^{17}$ Alessandro Alverà adds that the lectures often served as a platform for lively discussions that were primarily led by the more mature students (Alverà 2003: 98). "In the ensuing discussion on the respective topic we discussed, on the same level, in the most engaged manner. Often, very critical voices could be heard" (99). Thus, even with only letting a few voices speak, a complex image of a strict, at times unrelenting, but helpful teacher begins to form-one who fostered discussion but may have ignored positions he disliked.

A good designer does not necessarily make a good design teacher. How does Plischke compare in this sense? In his autobiography, Plischke remembers:

My aim however was not to produce nothing but small Plischkes, but rather to foster the strengths of the individual students, in order to help them become independent architects, able to expand, who would keep up my Baugesinnung (mindset relating to architecture) (Plischke 1989: 423). ${ }^{18}$

There are two parts to this quote: first, in a conversation, Luigi Blau answered the question of whether Plischke had tried to educate "small Plischkes". Blau thought Plischke had not, saying: "Even if Plischke did not really listen very well, he however tried to read the design attempts of the students as best as possible in order to help them, as best as he could" (L. Blau, personal communication, August 30, 2016). The other part of the quote refers to the Baugesinnung, a neologism made up by Plischke. "Bau" means building or "bauen": to build. "Gesinnung" is more difficult: attitude, mindset, beliefs, all these could be "Gesinnung" but it is also an old-fashioned word. What Plischke means by it is a noble mindset that underlies all architectural activity-in fact, a philosophical stance towards life in general that is characterised by humility and the above-mentioned inwardness (Innerlichkeit). What he, according to his former students, tried to achieve on a daily basis was to help them understand and continue this underlying humble stance towards architecture. In a lecture in 1965, Plischke said: "The Baugesinnung is a matter of knowledge, of restraint, of tact" (Plischke 1965a). ${ }^{19}$

\section{Studio Teaching: Light-Weight Structures and a "New Landscape of Living"}

Towards the end of the 1960s, when changes in study organisation and content were discussed all over the world, Plischke seems to-once again-have been in an ambivalent position: on the one hand, he attracted many students from 
Roland Rainer, who, as Viennese contemporaries tell, was very authoritarian; and maybe, Plischke's personal attitude helped avoid a severe clash between professor and students, as Alverà suggests in the above quote. On the other hand, Plischke was not entirely of this new time. He was a staunch modernist and did not agree with postmodernist ideas at all.

But this does not mean that he would have been anachronistic in the sense suggested in the section above. While he did not show much interest in blob structures as they were en vogue with the students in the early 1970s, organic and tensile constructions-above all Frei Otto's Munich Olympic Stadium-formed a core part of Plischke's teaching and are reflected in his students' works. Thus, the publication on work by students of Plischke's Master class of 1976, entitled Designs and Projects, opens with the illustration of a structural model used for the class's exhibition in 1967, an elegant tectonic sculpture made of metal, mesh, and string, by one of the students, based on purely tensile and compressive forces within the structural members (Plischke 1976: 9).

"Organically differentiated" is the title of the first chapter, showing tensile structures, space-frames, and tectonically expressive structures. These works are very different from Plischke's own designs and perhaps somehow surprising when compared with his site-inflected modernist houses, but it appears that he had a great interest in exploring the possibilities of such elegant lightweight structures. The other main trajectory of Plischke's design teaching has to do with urban planning. Soon after his return to Vienna, Plischke took a small group of students to the old Danube river arm outside the city, to introduce a project for a new district, or one could even say for a whole new city outside the existing city centre of Vienna, called Wohnbezirk Alte Donau—“Residential area old Danube”.

In the accompanying text and in the respective chapter of his autobiography, Plischke refers to his own experiences with housing and community planning schemes. He speaks of wishing to develop an alternative to the Viennese courtyard housing projects of the 1920s. As a student, Plischke had worked briefly on drawings for Karl Ehn's famous project of the Karl-Marx-Hof and had, so he remembered, despised its monumentality (Plischke 1989: 72). He had also submitted a project for another courtyard scheme competition, together with his American friend William Muschenheim. Strangely, Plischke never appreciated the tenement blocks of "Red Vienna", despite their achievements both in urban design and in liveability for the tenants. From his days in Vienna onwards, he always preferred the model of the Siedlung, smaller scale houses with adjacent gardens in a much lower density. "There is no doubt for me that the single family house, whether as terraced house or detached, constitutes the best form of living, particularly because of its garden" (Plischke 1976: 68). ${ }^{20}$ One could easily say that with this preference in mind, the New Zealand way of living suited him more than the typical Viennese density. In this publication text and in his autobiography, he mentions as precedents both his hometown Klosterneuburg (for its size of ca. 25,000 inhabitants and its density), together with his community designs for Trentham or Naenae, north of Wellington (Plischke 1989: 451-55). Plischke suggested a Neue Wohnlandschaft, a new landscape of living (1976: 69).

This project of autumn 1963 was indeed forward-looking in two respects: the so-called Donau-City became reality after 1990 and, with the United Nations buildings, forms a new high-rise area outside the city of Vienna. With the 
Wohnbezirk Alte Donau, Plischke also anticipated the many harbour revitalisation projects all over the world that were to be realised from the 1990s onwards.

Most of the student projects, however, employed a much higher density than those two precedents. The illustrations also demonstrate that the students were given substantial freedom to develop their own interests. What the publication overall demonstrates is that Plischke did not mind so much if a student designed in an architectural language different from his own preference. What remained crucial was that students stayed away from formalism and utilitarianism.

\section{Conclusion: Teaching or Practice}

Plischke was as devoted a teacher of design as he was an architect. The publication of his former students in 2003 speaks of this devotion, as discussed here. Much to his regret, Plischke did not receive many more architectural commissions after his return to Vienna. He was merely able to realise one school building and two more houses, with the Frey House in Graz (1970-73) an accumulation of his life-long experiences in bringing function, space, structure, and Bauplastik into one. Such lack of commissions, however, meant that he was now able to devote his time almost exclusively to teaching. It is perhaps the irony of history that thus, in Vienna, he-involuntarily-fulfilled one of two main requirements that the commission for the Auckland professorial post had set. Similarly, in the late 1940s, he would have been the professor that the Academy of Fine Arts in Vienna wanted him to be. In Auckland, he would have tried to bring practice and teaching as closely together as possible-exactly what the expectation was at the Academy in Vienna when he was appointed in 1963. The Academy wanted him to participate in public debate-much more than he did. This situation perhaps then characterises Plischke: that he was always somewhat out of place. Or, as he had written to his brother-in-law, the painter Max Frey, in 1939: "It is the outland/foreign that attracts me ... The foreign, between which one lives without really belonging-the air and the distance to ones surrounding” (Plischke n.d., ca 1939: 6). ${ }^{21}$

\section{Acknowledgement}

This article is part of a bigger research project on Ernst Plischke. This includes a book in the German language about to be published in Vienna, and which is planned to be published in English also. An earlier version of the article was presented at "Educating Architects and Planners, 1912-2017", a symposium at the University of Auckland in 2017. I am grateful for the opportunity to discuss Ernst Plischke's contribution to architectural education. All translations from German are my own, unless noted otherwise. 
6 "Professor L. B. Budden, Professor of Architecture, University of Liverpool, in the Chair, Mr. Martin S. Briggs, Senior Vice-Chairman of the Board of Architectural Education, R.I.B.A.; Mr. C. St. Clair Oakes, Senior Master of the Architectural Association School of Architecture; Mr. S. Ziman representative in Great Britain of the University of New Zealand; Mr. J. F. Foster, Universities Bureau of the British Empire (Secretary)" (AUC 1947: 380).

${ }^{7}$ It appears that the records for the Auckland School of Architecture for the year 1947 have gone astray. Information kindly provided by Elizabeth Nichols, Auckland University Records Management

ENDNOTES

${ }^{1}$ Though published in Sarnitz and Ottilinger (2003), Orosz's catalogue was unfortunately not included in the English edition of this book (Sarnitz \& Ottilinger 2004).

${ }^{2}$ In this letter to Rie, Plischke refers to the lectures having taken place "this last winter", i.e. mid-1941.

${ }^{3}$ Linda Tyler suggests that Firth wrote the specifications for the house Plischke designed for Otto Frankel in Christchurch in 1939-40 (Tyler 1996: 34). See also Firth's job diary of the years after 1944. Cedric Firth Papers, No. 94-132, Alexander Turnbull Library, Wellington.

${ }^{4}$ First set up as Bachelor of Architectural Science, it had by 1933 become the Bachelor of Architecture (BArch) that remained in place until the introduction of the Master of Architecture (Professional) (MArch(Prof)) (Treep 2017: 27).

5 "In 1907, the League of Empire sponsored an Imperial Conference on Education; in July 1912, the first Congress of the Universities was held in London, representing 53 universities and with $60 \%$ of delegates having had direct experience of living and working in the Empire. A Central Universities Bureau of the British Empire was established at the Imperial Institute in 1913" (Bush 2014; see also Pietsch 2013). having just sent Lucie Rie a copy of the book, meaning it was published by this date.
, kar wurde, bin ich sehr, geworden."

"Plischke (1947, June 14) reports
12 "Wir leben hier in unserem lieben alten Haus und schönem großen Garten seit über zwanzig Jahren. [...] Bevor ich mich aber innerlich zuviel damit auseinandersetze, was eine neue Entwurzelung und Rückverpflanzung mit sich bringen würde, ist es notwendig, in einigen Punkten klarer zu sehen."

13 "Das Ziel einer vollentwickelten modernen Architektur muß meiner Ansicht nach eine Einheit sein zwischen einem räumlichen Konzept einerseits und einer Bauplastik andererseits. Diese beiden Qualitäten müssen aber aus der Erfüllung der Funktion des Bauwerkes und seiner Konstruktion erarbeitet werden. Die wesentliche Qualität einer solchen vollentwickelten Architektur liegt in der Spannung zwischen dem Raumkonzept und der Funktion einerseits und zwischen der Vision einer Bauplastik und der Konstruktion andererseits. Es ist erst diese Spannung, welche einen Bau lebendig macht und zu einem Spürbar-werden seiner Architektonik führen kann. Ohne diese Spannung haben wir entweder einen reinen Utilitarismus oder eine abstrakte Bauplastik."

14 "Bei meinem Übertritt war es eine große Überraschung für mich zu sehen, dass die Plischke-Schüler nicht über ihren Professor schimpften, wie es an anderen Schulen damals üblich war. lch denke, dass Plischkes Vorlesungen sowie seine Lehrmethode die Loyalität seiner Schüler begründeten."

15 "Sie folgten einer Haltung und suchten dies moralisch und politisch zu begründen. Dabei ließen sie aber vieles, was sich tatsächlich in Politik und Gesellschaft in diesen Zeiten entwickelte, außer acht."

16 "Als Ganzes zeigt das Bild eine Übereinstimmung von Mensch und Werk."

17 “'Dieses auf den ersten Blick didaktisch unklar aufgebaute Konzept verdrängte den Studenten als Konsumenten, es verlangte Ausdauer und Geduld."

18 "Mein Ziel war es aber nicht, lauter kleine Plischkes zu produzieren, sondern die Stärken der einzelnen Studenten zu fördern, um selbständige und entfaltungsfähige Architekten aus ihnen zu machen, die meine Baugesinnung aufrecht erhalten."

19 "Die Baugesinnung ist eine

Sache des Wissens, der Zurückhaltung, des Taktes."

20 "Es besteht für mich kein

Zweifel, daß das Einfamilienhaus, ob als Reihenhaus oder freistehend, die beste Wohnform ist; vor allem aber wegen seines Gartens."

21 "Es ist die Fremde, die mich anzieht ... Das Fremde, zwischen dem man lebt, ohne so wirklich dazu zu gehören-Die Luft und der Abstand zu seiner Umgebung." 


\section{REFERENCES}

Academy of Fine Arts Vienna. (1960, June 24). Minutes of the 6th Faculty Meeting, Academic year 1959/60. Archive of the Academy of Fine Arts Vienna.

Academy of Fine Arts Vienna. (1962, May 23). Minutes of the 4th Faculty Meeting, Academic year 1961/62. Archive of the Academy of Fine Arts Vienna.

Alverà, A. (2003). Vermittlung. In F. Kurrent \& W. Stelzhammer Ernst Anton Plischke: Architekt und Lehrer (pp. 100-109).

Salzburg: Anton Pustet.

Architectural Group. (1946). Constitution of the Architectural Group. Republished in J. Gatley (Ed.), (2010). Group Architects: Towards a New Zealand architecture (p. 20). Auckland: Auckland University Press.

Auckland University College. (1947). Council Minutes. Volume 1. Registry Archive, University of Auckland.

Beaglehole, A. (1988). A small price to pay: Refugees from Hitler in New Zealand 1936-46. Wellington: Allen \& Unwin and Department of Internal Affairs.

Berger, P. (2007). Kurze Geschiche Österreichs im 20. Jahrhundert. Vienna: Facultas.

Bowron, G. (2000). Firth, Cedric Harold. Te Ara-The Encyclopedia of New Zealand. Retrieved from https://teara. govt.nz/en/biographies/5f6/firthcedric-harold

Bush, B. (2014). Review of Pietsch (2015). Review no. 1541. Retrieved from http://www.history.ac.uk/ reviews/review/1541

Firth, C. (1948, July 9). Letter, New York, to E. Plischke. Plischke Archive, Academy of Fine Arts, Vienna.

Gatley, J. (1996). A contemporary dwelling: The Demonstration House. In John Wilson (Ed.), Zeal and crusade: The modern movement in Wellington (pp. 89-95). Christchurch: Te Waihora Press.

Gatley, J. (Ed.). (2010). Group Architects: Towards a New Zealand architecture. Auckland: Auckland University Press.
Gatley, J. (2017). After Knight comes Light (and Toy). In J. Gatley \& L. Treep (Eds.), The Auckland School: 100 years of architecture and planning (pp. 40-73). Auckland: School of Architecture and Planning, University of Auckland.

Gatley, J., \& Walker, P. (2014). Vertical living: The Architectural Centre and the remaking of Wellington. Auckland: Auckland University Press.

Holzmeister, C. (April 6, 1960). Letter to E. Plischke. Archive of the Academy of Fine Arts, Vienna.

McCarthy, C. (2010). Imagining Prof Plischke. In M. Chapman \& M. Ostwald (Eds), Imagining... Proceedings of the 27th International SAHANZ Conference (pp. 258-264). Newcastle, NSW: Society of Architectural Historians, Australia and New Zealand.

Orosz, E. (2003). Catalogue of works. In Sarnitz \& Ottilinger (2003).

Paul, J. (1998). Ernst Plischke. In James Bade (Ed.), Out of the shadow of war: The German connection with New Zealand in the twentieth century (pp. 192-199). Auckland: Oxford University Press.

Pietsch, T (2013). Empire of scholars: Universities, networks and the British academic world, 1850-1939. Manchester: Manchester University Press.

Plischke, A. (n.d.). Letter to $\mathrm{Dr} R$. Lang. Carbon copy. Archive of the Academy of Fine Arts, Vienna.

Plischke, E. (n.d., ca. 1939, August). Letter to M. Frey. Private archive, Vienna.

Plischke, E. (1941, September 15). Letter to L. Rie. Private archive, Vienna.

Plischke, E. (1943, April 19). Letter to L. Rie. Private archive, Vienna.

Plischke, E. (1943, September 30). Letter to L. Rie. Private archive, Vienna.

Plischke, E. (1947, February 3). Application for Chair of Design, Faculty of Architecture, Auckland University College. Plischke Archive, Academy of Fine Arts, Vienna.

Plischke, E. (1947, May 26). Diary entry.
Plischke, E. (1947, June 1). Letter to his family, Vienna. Private archive, Vienna.

Plischke, E. (1947, June 14). Letter to L. Rie. Private archive, Vienna.

Plischke, E. (1949, October 17). Letter to L. Rie. Private archive, Vienna.

Plischke, E. (1960, January 18). Letter to R. Rainer. Archive of the Academy of Fine Arts, Vienna.

Plischke, E. (1960, May 20). Letter to L. Rie. Private archive, Vienna.

Plischke, E. (1965, January 12). Lecture. In A. Alverà (2003).

Gehört und Geschrieben.

Auszüge aus den Dienstag-

Vorlesungen von EAP. In F.

Kurrent \& W. Stelzhammer, Ernst

Anton Plischke: Architekt und

Lehrer (p. 109). Salzburg: Anton Pustet.

Plischke, E. (1965, November 24). Die Vielfalt der bildenden Kunst in der Welt von heute. Inaugural Speech at the Academy of Fine Arts Vienna.

Plischke, E. (1976). Entwürfe und Projekte: Meisterschule E. A. Plischke. Vienna: Prachner.

Plischke, E. (1989). Ein Leben mit Architektur. Vienna: Löcker.

Posch, W. (2010). Clemens Holzmeister. Architekt zwischen Kunst und Politik. Salzburg: Müry Salzmann.

Rainer, R. (1960, January 4). Letter to E. Plischke. Archive of the Academy of Fine Arts, Vienna.

Registrar, Auckland University College. (1947, May 20). Telegram to E. Plischke. Archive of the Academy of Fine Arts, Vienna.

Salinger, L. (1996). A breath of fresh air: The Architectural Centre Inc. In John Wilson (Ed.), Zeal and crusade: The modern movement in Wellington (pp. 69-78). Christchurch: Te Waihora Press.

Sarnitz, A., \& Ottilinger, E. (Eds.). (2003). Ernst Plischke: Das Neue Bauen und die Neue Welt. Munich: Prestel. Republished in English as: Sarnitz, A., \& Ottilinger, E. (Eds.). (2004). Ernst Plischke:Modern architecture for the new world. Munich: Prestel.

Schnoor, C. (2014). Between Werkbund and wartime sobriety: Ernst Plischke's designs for
Orakei. In C. Schnoor (Ed.), Proceedings of the Society of Architectural Historians, Australia and New Zealand: 31, Translation (pp. 805-816). Auckland: SAHANZ and Unitec ePress; and Gold Coast, Queensland: SAHANZ.

Spühler, M. (2003). Reflexionen eines Schülers aus der Schweiz. Vermittlung. In F. Kurrent \& W. Stelzhammer, Ernst Anton Plischke: Architekt und Lehrer (pp. 130-133). Salzburg: Anton Pustet.

Steiner, D. (2003). Meine Anna sollte hier mit anderen Frauen in der Küche stehen?". In F. Kurrent \& W. Stelzhammer, Ernst Anton Plischke: Architekt und Lehrer (pp. 126-128). Salzburg: Anton Pustet.

Treep, L. (2017). "A school of architecture for the dominion": The first years. In J. Gatley \& L. Treep (Eds.), The Auckland School: 100 years of architecture and planning (pp. 14-39).

Auckland: School of Architecture and Planning, University of Auckland.

Tyler, L. (1996). The urban and urbane: Ernst Plischke's Kahn House. In John Wilson (Ed.), Zeal in crusade: The modern movement in Wellington (pp. 33-38). Christchurch: Te Waihora Press. 